\title{
Interpellating Hyphenated Medusas: Pearl Cleage's Chain and Rhodessa Jones' Big Butt Girls, Hard Headed Women
}

\author{
Dr. Naeema Abdelgawad \\ Assistant Professor \& Independent Researcher \\ Literature and Translation \\ Cairo, Egypt \\ n_gawad@hotmail.com
}

Here they are, returning, arriving over and again, because the unconscious is impregnable. They have wandered around in circles, confined to the narrow room in which they've been given a deadly brainwashing. You can incarcerate them, slow them down, get away with the old Apartheid routine, but for a time only. As so as they begin to speak, at the same time as they're taught their name, they can be caught that their territory is black.

Hélène Cixous, "The Laugh of the Medusa"

1975 , p. 877

Monomaniac phallic acculturation aligns femininity with whatever attributes repudiated by the masculine world. A male is deemed to be the locus of power and restraint within the family, as well as, its representative in the outer world. In contradiction, a female is commonly associated with passivity, masochism and narcissism. This phallogocentric notion is originated in a misogynic patriarchal ideology that gives rise to the leitmotif of female otherness. The perception of gender boundaries is necessary for males who promote their logic of dualism through incarcerating females into only two fixed metaphors: Angel or 
Mad. Pearl Cleage ${ }^{1}$ and Rhodessa Jones ${ }^{2}$ in their plays Chain (1991) and Big Butt Girls, Hard-Headed Women (1990), respectively, press against the externally and internally imposed boundaries confining the African American feminine expression. Theirs is a concurrent issue which gives a collective redefinition of sisterhood; they do not only seek helping black females, but also any female to transcend the downgrading destructive oculocentric, patriarchal ideologies deadening females' spirit and capability of choice. Coinciding with Louis Althusser's quest of the way ideology functions in society, the article attempts to explore the metaphorised representation of females through an Angel/Mad binary as well as to examine the prejudiced Freudian psychosexual interpretation of females created by patriarchal Ideological State Apparatus in the context of the Althusserian concept of interpellation.

Keyword: Althusser, Interpellate, Freud, Angel, Mad.

Interpellation for Althusser is a key term that delves into the nature and function of ideology as well as subjecthood. Althusser believes that interpellation describes the constitutive process of ideology, which hails or interpellates a subject-in-becoming in his/her pre-ideological and abstract status so as to turn him/her into subject. He confirms that 'all ideology hails or interpellates concrete individuals as concrete subjects'; noting that the primary intention of ideology is 'constituting individuals as subjects' (Althusser, "Lenin before Hegel" 1969 , p. 115, 116). Interpellation is simultaneous in nature as it is not governed by cause and effect, the same way he thinks a subject is. Althusser's example is a 'hello' in the street. It interpellates the abstract pre-ideological individual and turns him/her into subject. Accordingly, interpellation, ideology and subjecthood are overlapping; 'the existence of ideology and the hailing or interpellation of individuals as subjects are one and the same thing' (Althusser, "Ideology and Ideological State Apparatus" 1969, p. 175); each 
one of them reinforces the others. Althusser adds, 'Ideology has always-already interpellated individuals as subjects, which necessarily leads us to one last proposition: individuals are always-already subjects' (Althusser, "Ideology and Ideological State Apparatus" 1969, p. 176). He also confirms that one's subjectivity exists, 'always-already', and is discovered through the process of interpellation in which ideology produces a subject. Thus, both interpellation and ideology are omnipresent when taking into account how subjects are constituted through the Ideological State Apparatus (ISA) ${ }^{3}$.

The metaphorised representation of females into the Angel/Mad binary invokes the concept of interpellation, as females turn into a mere effect of social relations and ideologies; a process in which their subjecthood is influenced. Noting that individuals acknowledge and respond to the ideologies through which they recognise themselves as 'subject', their subjecthood is, therefore, formed according to the dominant Ideological State Apparatus (ISA) which serves the objectives of the State Apparatus (SA) ${ }^{4}$. Taking into account the patriarchy as an effective and dominant ISA in society, because it controls and basically forms the ideologies of family, education institutions, literature and also the media, females are interpellated through various mediums whose original source is the patriarchy. Knowing that 'the existence of ideology and the hailing of individuals as subjects are one and the same thing' (Althusser, "Ideology and Ideological State Apparatus" 1969, p. 175), the patriarchy, as the constituting power structure in society, has the power to form the existence of females and to predetermine their position in society. The patriarchy is compared to the systems that Althusser often criticises, it is 'a system containing every combination of pre-given elements, but in a potential rather than actual state' (Dal Maso-Montag 2018). Through the hegemonic ideologies of the patriarchy, the metaphorised representation of females creates 'false consciousness' which initiates false understanding of the way the world functions (Althusser, "Lenin before Hegel” 1969, p. 108). Females become conscious of the nature of 
their existence through the ideologies promulgated to them. Through practice and everyday life, females become convinced of the attributes ascribed to them, which source is, certainly, the patriarchal ISA that instructs them how to communicate and respond to life challenges. 'Communication is a process in which humans produce and reproduce social relations in manners that mediate not just understanding the world and other humans, but also the dialectic of structure and agency and the dialectic of society's realms' (Fuchs 2019). Thus, females hold the patriarchal ISA ideologies as true because its existence materialises to the extent that it incarcerates females into the Angel/Mad metaphor; 'an ideology always exists in apparatus, and its practice, or practices' (Althusser, "Lenin before Hegel” 1969, p. 112). Accordingly, a female under the patriarchal ISA communicates with the society in a way that is specially pre-determined for females.

Pearl Cleage is an African American author of fiction and non-fiction. She decided to write about the issues and problems of people she encounters. Her interesting and vivant plays are mainly designed to educate the audience how to overcome everyday life challenges. However, she believes that her plays should be interesting enough to entice the audience to absorb her message. In an interview with Morgan Mims, Pearl Cleage confirms:

Part of my job, I think, is to make my stories so interesting and my characters so real and so vibrant that the issues are indistinguishable from the lives I am presenting for your consideration. Nobody comes to the theatre to be preached about issues. I think most people want to feel something at the theatre (Mims 2016).

Cleage's realistic dramas also spotlight the difficulties that youth confront while growing up. She believes that it is not easy to deal with the world outside the boundary of the family. She went through this issue with her sixteen-year daughter, whose problems are compared to many other teenagers at her same age bracket. Their teenage confrontation with the outer society might develop complications that would easily destroy their future. In a 
recent interview, Cleage confirms that she tackles the responsibility of representing on stage stories of females 'trying to deal with all the outside world' so as to give the audience the opportunity to compare whatever the behold on stage with their own personal issues so that they would 'see the rough edges and see that even though life is messy and the journey is always messy, that you can keep moving forward and figure it out' (Martin 2014). Cleage aspires to better her society.

Considering Rhodessa Jones, she is a San Francisco actress, teacher, singer, and writer as well as a co-artistic director of the San Francisco-based theater company Cultural Odyssey and the founding director of the Medea Project: Theater for Incarcerated Women. Jones thinks of all her work as 'telling the truth and practicing revolution' (Janiak 2018). Her revolutionary perspective started when she was asked to teach aerobics to imprisoned women. Listening to the stories of the incarcerated females, she realised that their stories deserve to be told. Those stories helped Jones generate an autobiographical theatre depending upon storytelling, an art that she learned from 'her grandmother and her aunts'. Rhodessa Jones believes that 'the art of autobiographical theater and storytelling [would] support the most vulnerable people to heal collectively" ("Rhodessa Jones" 2020). Her plays are real therapeutic pieces that would exhort and educate by bringing on stage real experiences of females that the audience encounter in their everyday lives.

Chain (1991) and Big Butt Girls, Hard-Headed Women (1990) deal with marginalised females who constitute the wide majority of the African American society. Most of them are underclass females: drug addicts, whores and criminals; 'women who are intentionally silenced and ostracized by the systems of power in this country, women in prison' (Elam 1996, p. 9). Yet, these females, like any other ones, are metonymically incarcerated within the patriarchal ISA that always forces them to be incarcerated in the position of a dependent follower. Within the outer prison of the phallocentric society, the presence/absence 
of males is fatal; it deracinates the feminine ideology, and, further, frames femininity to their own ideal image. Patriarchal thought has created an incoherent version of femininity, in which the women who live it are trapped, and for which they are blamed. Their 'nature' is culturally constructed, but the construction is disguised - and, after all, nature is precisely the thing that one cannot change. (Robins 2000, p. 59)

Mishandled as they are by the patriarchal ISA, females are trapped in a dominance/submissiveness scheme whose diligent followers are rewarded by being dubbed 'Angels,' while the dissenters are called 'Mad.' The patriarchal urban culture defines the 'Angel in the House' as a perfect lady who is 'contently submissive to men, but strong in her inner purity and religiosity, queen in her own realm of the Home' (Showalter 1981, p. 274). ${ }^{5}$

The patriarchal ISA poking the like definitions interpellates the subjecthood of females. Knowing that ideology, as Althusser defines it, is 'the imaginary relationship of individuals to their real conditions of existence,' and, moreover, it serves as a 'mediator' between the system of power and individuals (Althusser, 1969, 'Ideology and Ideological State Apparatus,' p. 162), the duality of domination/subjugation which gives way to dominance/submissiveness is raised. Althusser's example of a police officer who shouts out 'Hey, you there!' in public is applicable upon the status of females who are incarcerated in the metaphorised Angel/Mad representation promulgated by the patriarchal ISA. Althusser proceeds, upon hearing this exclamation, an individual turns around and 'by this mere onehundred-and-eighty degree physical conversion, he becomes a subject' (Althusser, 1969, 'Ideology and Ideological State Apparatus,' p. 174). Althusser here complicates the process of domination/subjugation when he pinpoints the interpellation process where individuals recognise themselves as subject. His example reveals that recognition of subjecthood is a double-faced process in which an individual feels that law gives him/her the right to be subject, but, at the same time, he/she are subjugated by the law. Accordingly, Althusser 
thinks that through ideology, the hegemonic power is capable of reproducing itself through 'obscuring' traditional forms of repression and 'incorporating the individuals into the power structure' (Althusser, 1969, 'Ideology and Ideological State Apparatus,' p. 162). Similarly, the patriarchy which forms the SA and promulgates the ISA is the hegemonic power that keeps its domination through ideologies that subjugates females; the metaphorised representation of females is an example. The approved type of females who are rewarded by being called Angels are deceived when they conceive that they are incorporated in the power structure unconscious that the patriarchal hegemony reproduces itself through such representation. The result is a systemised process of dominance/submissiveness that interpellates the subjecthood of females.

Pearl Cleage's Chain represents four patriarchal types of the perfect ladies or 'Angels in the House.' Yet, in Rhodessa Jones' Big Butt Girls, Hard-Headed Women there are none, except for Rhodessa Jones herself, all of them are incarcerated because of their insurgence that is deemed Madness. In Chain, Rosa's grandmother is a romantic Angel who lives in the vast rural area of Tuskegee to which Rosa always refers as Eden where she and her family used to lead a happy perfect life. While Rosa is almost fifteen, she is sent to live with her grandmother who uses every possible way to restructure Rosa's character in consistence with the patriarchal ISA that forms her character. When she hears Rosa cursing on the phone, the gransmother becomes offended as if this were a sacrilege to her Eden. Rosa recalls:

She hang up the phone and took me in the bathroom and washed my mouth out with Ivory soap. I was almost fifteen years old, but grandmothers don't care about your real age. They got a [sic] age they want you to be and that is the age you gonna be when they around. (Chain 1991, p. 277). 
Hoarding as true the patriarchal ISA, the Angel-type females, believing that they are 'incorporated into the power structure', become another inferior copy of males. Compared to the SA itself, they become repressive and, at some point, see the necessity of using violence; they neither consider the psychological differences nor the needs of younger generations. Rosa's grandmother becomes an Angel in her male-created Eden. Yet, compared to Angels, she is, undoubtedly, invisible. When Rosa steals her grandmother's social security check, Rosa's grandmother cannot claim her usurped propriety except at the presence of Rosa's uncle, as if male presence would render her visible. Living alone in a romanticised Eden version of a 'Home,' the death of Rosa's grandmother means nothing for her New York dweller son, Rosa's father; who is also an active promulgator of the patriarchal ISA. He calmly receives the news and never sheds a tear. Rosa's account of her grandmother reveals that she hoards an ecofeministic ${ }^{6}$ view of this elderly lady whose example of 'Angel in the House' she despises. When violently expelled out of her grandmother's Eden, Rosa becomes happy and decides to never return back again. Rosa's grandmother is not only a representative to the duality of dominance/submissiveness, but also to that of exploitation/victimisation because she, unconsciously, reproduces the patriarchal hegemonic power. Both dualities are abhorred by females who are keen to develop self-esteem and high self-image.

Rosa's mother belongs to the submissive type of Angels. She is stamped with the duality of exploitation/victimisation that metamorphoses into a 'happy house wife syndrome' that moulds her, certainly, from a patriarchal perspective, into 'the ideal image of womanhood' (Devine 1992, p. 74). She is subject to a complex victimisation process in which she is deprived of feminine expression. Rosa's mother, blindly, follows her husband when he takes her away from the rural den of Tuskegee to the inferno of the Harlem ghetto where she is transformed into a worn out Angel working from early hours of the day until late at night. He also deprives her of the expression of her motherhood when he assumes her role 
as mother; he undertakes the task of nursing and reforming Rosa and, above all, occupying her daydreams. The day they retrieve Rosa, her mother keeps crying and does not utter a word. She never objects when her husband chains Rosa; 'she looked at me and then she grabbed her purse and ran out of the room. Then it was just me and Daddy,' says Rosa (Chain 1991, p. 273). In the shade of the all-normative and all-encompassing patriarchal culture, Rosa's mother becomes an excruciatingly weak, submissive and negative Angel who is able to help nobody; including herself. Rosa's mother is the product of the patriarchal ISA which interpellates females and calls them Angels when they become totally submissive to the extent that they adopt whatever ideologies passed to them by the patriarchal ISA; no matter if they were destructive. At this point, as Keith Sawyer believes, they reach 'the moment and process of recognition of interaction with the ideology' (Sawyer 2002, p. 438). Such an interaction turns Rosa's mother, so as her likes, into a mere effect of social relations; a process that jeopardises her subjecthood.

Jesus' mother, the Puerto Rican Third World female, represents another type of Angels; namely, the masochistic. She shoulders the harsh task of assuming a mother-father figure; to her son, she is the mother and the breadwinner. She plays the same role with her boyfriend and, also, accepts all his violence and abuse under the pretext that she reforms him. At the end, he relentlessly murders her, as he believes that the dope is far better than her sacrifices which might strip him of his authority and declare her victorious autonomous female. 'As is so frequently the case in the history of sex relations, men view the smallest female steps towards autonomy as threatening strides that will strip them of all authority' (Gilbert 1988, p. 66). Males are content with the victimisation of females because this guarantees a perpetual hegemony. 
The last type of Angels is the narcissist of whom Paula, Rosa's Italian friend, is an example. Paula wears the mask of an insurgent female defying the monolithic notions of patriarchy. She is smoker and daring; 'she say [sic] anything to people and just walk away' (Chain 1991, p. 273). The others' reaction to her insurgent behaviour is becoming 'surprised' or 'start laughing;' 'that's cause she cute. They don't care what she say cause they like looking at her while she standing there saying I' [My emphasis] (Chain 1991, p. 274). Paula's beauty is her passport to the oculocentric male world that lurks for her insurgence that would, at the end, make her suffer the consequences of a designed narcissism. Further, she is seduced to invade more patriarchal domains through promiscuous relationships till she gets pregnant. As a consequence, she regresses to the traditional submissive and passive image of a female who is pushed into motherhood; she stops smoking and yields to her males' sexual desires in spite of being pregnant. Though the ideals of femininity and masculinity change over the ages, the concepts of male and female, relatively, remain constant. The oppression of women is, fundamentally, achieved by 'imposing certain social standards of femininity on all biological women,' whereas feminism 'insists that though women are undoubtedly female, this is in no way guarantees that they will be feminine' (Moi 1985, p. 65). This refers to the fact that femininity and autonomous feminine ideology are claimed not gained.

Considering that the wide majority of individuals, i.e. subjects, accept their ideological self-constitution as 'reality' or 'nature', the same way that females do, as they become unconscious to the repressive State Apparatus (SA) which is designed to punish whoever dares to reject the dominant ideology that produces a common status of submission/victimisation; as for the ISA, it paves the way to hegemonic power structure that maintains the control of the SA. Althusser argues that 'the individual is interpellated as a (free) subject in order that he shall submit freely to the commandments of the subject, i.e., in order that he shall accept his subjugation; in order that he shall make the gestures and actions 
of his subjugation 'all by himself' (Althusser 1969, 'Lenin before Hegel,' p. 123). Rosa's grandmother, Rosa's mother, Jesus' mother and Paula freely submit to the created patriarchal culture that subjugates females. Each one of them ends as a slave to such repressive SA and ISA because they had to choose to be incarcerated into the binary of exploitation/victimisation so as to be recognised as Angels.

The other version of femininity is that of the Mad or the Medusas who are isolated and incarcerated lest they should corrupt the other females. Chain and Big Butt Girls, Hard-Headed Women are written in form of exterior monologues to assert the isolation and the incarceration of these females. In Chain, Rosa runs the show and gives an honest account on herself and her relationships. In Big Butt Girls, Hard-Headed Women, the same happens through Rhodessa Jones, the aerobics teacher of the inmates. She functions as the conduit of the stories of the fallen women who confide their stories to the audience and never appear communicating with each other; except in only one scene. Compared to Pearl Cleage, Rhodessa Jones introduces a matrix of black feminine experiences and plays the role of the psychological helper who does not only assist these incarcerated women in eliminating the deformity of their shapes, but also in transcending the deformity of the self which stems out of the patriarchal ISA. Through a background of music tapes that Rhodessa Jones classifies as 'Niggas with Attitudes', she encourages prison inmates to effectively overcome the prison experience by being considered as a 'Spa' where they would contemplate their past and present as well as speculate a positive vision of the future. Remarkably, Jones is not ashamed of being a 'Nigga', she desires to celebrate her identity and teaches other inmates to follow her example. Jones makes her first appearance on stage as someone who angrily speaks with the prison ward; her language is not different from that of the fallen women who are commonly accounted Mad. Jones confirms that she and these females stand at the same footing of equality: 
I look out at all those faces. There's my mother's face, my sister's face, and my daughter's face. And I'm wondering how in the hell did they get here in the first place. And I realize that it is but for a flip of fate that it could be me in here and she out there. (BBG 1990, p. 367)

From a patriarchal ISA, Jones' attitude is that of a Mad female, yet, she enjoys self-control to the extent that she usefully employs her madness to assert herself, gain her rights, and challenge the patriarchal hegemony. In her essay, 'The Mad Woman and her Languages,' Nina Baym asserts 'French feminist literary theory appears to accept the figure of the mad woman as redemptive' (Baym 1984, p. 157). Thus, being Mad is not that repulsive because it might help give rise to a revolutionary spirit fighting imposed culture; it seems that Jones applies the same strategy.

While the constitutive process of ideology is a matter of interpellation, there is a contradictory trend of personal ideologies that interpellates Rosa, Rohodessa Jones and the inmates. Such personal ideologies are the force that prods women to express their subjecthood shamelessly. Personal ideologies also encourage them to escape boundaries of subjecthood that is a mere effect of social relations, no matter if these women were marked Mad. Accordingly, the hegemony of the patriarchal ISA that involves submission and repression and essentially caters for the objectives of the SA becomes threatened by another revolutionary one initiated by outcast Mad females. Due to the category of Mad females, the hegemonic interpellation heralded by the patriarchy remarkably fails as the patriarchy does not take into account the psychological status of a Mad female, in other words their "Third Text', which has the power to combat any process of submission/subjugation or exploitation/victimisation.

The subject deconstructs every message even if he is not trained in critical practice. $\mathrm{He}$ is interpellated or fails to be interpellated depending on what latent message was generated through a comparison with a Third Text. And because the Third Text includes All 
possible Texts, the subject is given to numerous competing interpellations offered by many ideologies at odds with each other. The subject is in an environment of competing interpellations. (Vaknin 2005, p. 28)

These 'competing interpellations' also produce competing ideologies according to which the constitutive process of ideology interpellates both categories; namely, the Angel and the Mad, making of them two competing polarities. When placed in a social context, these two competing polarities promulgate a set of ideologies; notably, each one of them struggles to create its own hegemonic power structure.

Under the patriarchal SA, the females in Rhodessa Jones' Big Butt Girls, Hard-Headed Women are isolated from the outer world by being literally incarcerated as punishment for acting madly. Those females are the victims of oscillating between their matrilineage and patrilineage in an arduous process of self-definition. Similar to all the Angels in Chain, they are battered under the duality of dominance/submissiveness.

Through the Roman Catholic Church, patriarchal authority by the Middle Ages had defined and promoted roles for women, they could most easily be controlled by physically and socially, namely, the virgin, the mother, and the whore. (Devine 1992, p. 11)

The prison walls enfold these same three categories; 'the virgin, the mother, and the whore'; though the first two refer to the Angel, while the last one to the Mad. Finding the trio of them in prison stamped as Mad attests to the falsity of the patriarchal ISA. Regina Brown under the patriarchal SA and the betrayal of her boyfriend becomes a prostitute. Describing her, however, Jones says: 'Regina Brown, whore with a heart of gold. . . Regina Brown, who, with a little direction, could have been running the world' ( $B B G$ 1990, p. 375). Regina's madness, for which she is punished, is defying submission and having high self-image; 'I'm my own woman,' says Regina (BBG 1990, p. 368). Compared to any Angel, she is a mother who is heartbroken because her baby is away from her. 
Incarceration within the context of the metaphor of 'Mad' is also the destiny of females who choose to practice their motherhood in defiance to the patriarchal traditions. Mama Pearl and Doris are considered Mad because they insist on protecting their children; in other words, practicing their motherhood. The essential problem of Mama Pearl is that her older daughter is born deaf and dumb. Thus, she embezzles some money from the company where she works to enable her daughter to get special training so that she might take care of herself. Similar to Rosa's grandmother, Mama Pearl is in her seventies and acts motherly towards everyone. Unlike Rosa's grandmother, Mama Pearl has a broader view of life. She also understands the needs of the younger generations and is capable of diagnosing the reason behind having young females transformed into fallen women; 'these men that pimp them for drugs, money, cars, even a leather coat' ( $B B G$ 1990, p. 369). Outside prison, shockingly, Mama Pearl is considered incorrigible and Mad because of her ideologies that are in conflict with the SA. She has been in and out of prison for thirty years for the same reason; namely, securing money for her handicapped daughter. Doris also sacrifices her future for the sake of her baby. She is taken to prison because she defends herself against a hegemonising and abusive policeman calling her a 'prostitute' and her baby a 'felon'. The policeman furthers his repressive and violent sexist assaults as representative of the hegemonic power structure of the SA, by physically mishandling her and accusing her of resisting arrest; an accusation for which she is sent to prison to stop acting 'Mad', it was expected that she should submissively accept whatever injustice done to her. In Chain, Rosa, who is to a great extent compared to Rhodessa Jones' characters, is a teenage with attitude whose search for self-assertiveness and defying submission makes of her a hardened dope-addict. For reform purposes, her father chains and locks her in a room, a solitary confinement. Despite Rosa is a virgin who desperately protects her virginity when assaulted, this does not make of her an Angel. 
In violation of the patriarchal taboos, the incarcerated females expose the falsity and the prejudice of the patriarchal ISA. Physically incarcerated as they are, 'women themselves have constituted a subculture within the framework of a larger society and have been unified by values, conventions, experiences, and behaviors impinging on each individual' (Showalter 1981, p. 373). In this subculture, or cultural enclave, these females provoke their social and behavioral paradigms so as to reach a proper self-expression according to the following arrangement: 'Feminine, Feminist, and Female' (Showalter 1981, p. 374). The wide majority of the incarcerated women successfully discover their identity away from the patriarchal urban culture. In incarceration, the inmates freely express themselves and perform their everyday activities; such as watching TV and reacting towards soap operas; as if they were enjoying a free life away from the prison walls. Rosa also gets used to her chains and adapts herself to move easily with them as if they were not there. Chain and Big Butt Girls, Hard-Headed Women do not just reflect or 'mirror' a society; they attempted to change it' (Carby 1995, p. 95) by teaching females that any type of madness, which is synonymous to assertiveness and independence, undoubtedly, leads to freedom and autonomous subjecthood. These Mad females succeed at creating of themselves a competing hegemonic polarity, which has a power structure that competes with the patriarchal one. Through their ideologies that are deemed madness, the literally or figuratively incarcerated females become representatives 'of power over other human beings' which underlines the fact that 'the failure of one interpellation - normally means the success of another' (Vaknin 2005, p. 29). The incarcerated Mad females constitute a competing culture when they insist upon rejecting predetermined behaviour patterns.

Being Angel or Mad, a female is also a human being who, compared to any female, has an id and ego that impel her to develop her ability to live within a social environment. They also pass through the same Freudian stages of a child's psychosexual development ${ }^{7}$. 
Regretfully, Freud leads sexist prejudiced attitude against women motivated by a cross-cultural singular notion of patriarchy that spreads a homogenous notion that asserts the inferiority of females so as their otherness ${ }^{8}$. The metaphorised representation of women and Freud's psychosexual analysis are a matter of culture industry through which certain ideologies are coined to interpellate a certain category; noting that in the process of culture industry, the details of an ideology change according to the situation. Determined to be defined as Angels, when females hoard the patriarchal culture industry promoted by a hegemonic ISA, they help perpetuate not only the patriarchal hegemonic power, but also their inferior status. All the types of females 'immovably, $[\ldots]$ insist on the very ideology, which enslaves them. The misplaced love of the common people for the wrong which is done them is a greater force than the cunning of the authorities' (Horkheimer 1979, p. 8). When females consent to the ideologies interpellating them as passive, they do not only agree on their inferiority but also grow satisfied with it.

Freud's harsh descriptions and prescriptions of females contribute to further their oppression. Starting from the moment of incarceration in Chain and Big Butt Girls, Hard-Headed Women, Freud's psychosexual theory is typically applied, but in reverse. Before incarceration, Mad females are in the genital stage. Incarceration is compared to the latency stage where both sexes tend to seek out same-sex playgroups. The miseries and conflicts within incarceration are similar to the games that the children play during infancy; games that are essentially educative. Rhodessa Jones' nephew echoes this fact in his letter to her when he says: 'This place [prison] can really be a great place to get your mind together. Even the violence and games that people play help you learn and grow' (BBG 1990, p. 377). Rhodessa's nephew gives voice to his experience as a male in penitentiary which also echoes what happens in the penitentiaries of females; this is a proof on the homogeneity of female and male psychology. Yet, the difference occurs only on basis of the patriarchal ISA 
promoting the strategy of separate development. During incarceration, which is compared to the latency stage, the imprisoned females begin regressing to self-centered periods of stimulation and gratification until they stop at the phallic stage; the stage of character formation. In this stage, they are safe and away from discriminating gender-roles, sexual assault and myths, and, clearly, start thinking about their attitude; not only of the physical imprisonment, but also of the devastating psychological incarceration.

Following Freud's psychosexual theory, Rosa by the close of her phallic stage starts a process of affection transference through making relationships with the other sex so as to grow up; because a 'woman's place in human social life is not in any direct sense a product of the things she does (or even less, a function of what biology she is) but the meaning her activities acquire through concrete social transactions' (Rosaldo 1980, p. 400). Rosa finds that her father is the appropriate figure, instead of, according to Freud, her castrated mother. Her immense love towards her father is based upon his qualities: cool nerves, strength, readiness to fight and the difficulty to get him impassioned. Nonetheless, the hectic city life separates them and renders him unable to back her and to consider her love for him. As a consequence, Rosa begins transferring her passion to another male figure enjoying her father's same qualities; namely, Jesus, whose name suggests that he is a saviour. Freud asserts:

Girls remain in it [the Oedipal stage] for an indeterminate length of time; they demolish it late, and even, so, incompletely. In these circumstances the formation of the super-ego must suffer; it cannot attain the strength and independence which give it its cultural significance. (Freud 1993, p. 88)

In contradiction to Freud's psychosexual theory, Rosa becomes affiliated to her father then to Jesus because they are strong, and accepted to develop a relationship with her. On the other hand, her relationship with her mother is not that strong, not because of Freud's anxiety 
of castration, but because Rosa abhors catching the syndrome of a silenced partner, or, in other words, the desired Angel of the phallic society. Getting out of the Eden of Tuskegee, Rosa discovers that the city is open for strong, visible people. Her attraction to Jesus is not based upon his gender, but rather qualities. It is her disappointment in her friendship with the strong Paula, who is finally subdued by males, that makes Rosa shift to Jesus.

Analysing Jesus' character through Rosa's frank account, from a Freudian perspective, it is revealed that he is a prisoner of the Oedipal stage. To him, the violent death of his angelic mother is equivalent to the discovery that his mother is castrated. Developing resemblance to the nearest male figure, the ready example is his mother's boyfriend who is a murderer, drug addict, bully, cool and self-centered. Nevertheless, Jesus' rejection of his phallic mother is not built upon the discovery of her, as Nina Baym (1984, p. 163) believes, 'appalling lack', but, similar to Rosa, upon the discovery that the real world has no place for invisible angels. The mask of his mother's boyfriend is also appropriate because it asserts that he has surpassed the Oedipal stage and become adult. Yet, deep inside, he knows that has not. His Oedipus complex is insurmountable; he confides to Rosa that 'he used to hear his mother and father fucking when he was real little and sometimes he'd pretend that his mother was doin' it with him instead of his father' ( $B B G$ 1990, p. 283). As a result, his love life becomes traumatic to the extent that he recoils from any real sexual relationship with any female on basis that he cannot do it with his mother. He also encourages Rosa, if she likes, 'to do it with somebody else, he wouldn't be pissed off, or nothing' (BBG 1990, p. 282). Compared to Jesus is Rosa's father. Probably, he leaves the south where he used to sing, laugh and show extremely angelic attitude towards everyone so as to cut his oedipal affiliation to his cherished mother who might turn him into another copy of her. Knowing about his mother's death, he neither sheds a tear nor attends the funeral, as if cruelty attests to his adulthood. It is not the 'girls' who 'remain' in the oedipal stage 'for an indeterminate length of time,' 
obviously, it is the males who do. It appears that Freud analyses the masculine world then ascribes the derogatory connotations that males repudiate to females. Unlike the 'girls,' the boys are interested in developing sexual difference because the core gender identity in boys is more conflictual and more problematic . . because of their initial close association ('a primary oneness') to the mother figure, boys have as part of their core gender identity 'an underlying sense of femaleness' that continually, usually, unnoticeably, but sometimes insistently challenges and undermines the sense of maleness. (Chodorow 1978, p. 13)

Males' psychological dichotomy prods them to ascribe the feelings and the psychological traumas that they are incapable of pronouncing to females in order to retain the coherent image of unprejudiced superior sex.

In Big Butt Girls, Hard-Headed Women, whatever denied outside prison walls is fulfilled inside. Mama Pearl, who cannot assume her role as a mother to her handicapped daughter because of her incarceration, capably plays the role of the phallic mother to the inmates who cherish and respect her. As for Regina Brown and Doris, their male relationships are mature and realistic. Regina's is for money, while Doris' is for having a father to her child; this attitude affirms that they do not suffer from any Castration Complex. Hélène Cixous gibing at the misogynic and patriarchal immature Freudian analysis of the phallic stage argues:

Too bad for [men] if they fall apart upon discovering that women aren't men, or that the mother doesn't have one. But isn't this fear convenient for them? Wouldn't the worse, isn't the worst, in truth, that women aren't castrated? (Cixous 1976, p. 885)

The prejudiced interpretation of the phallic stage produces psychological deformity that tightens the incarceration of females. Freud's psychosexual analysis of female psychology asserts a prejudiced patriarchal ISA which intends to incarcerate females into pre-determined roles. Freud's prejudiced theories are passed as real and true ideologies 
though a latent objective. Therefore, they are a means to perpetuate the hegemonic patriarchal power structure. The success of the Freudian perspectives over the ages, and, to a great extent, up to the present, is ascribed to the use of an infallible technique in which his 'ideology must not be seen to err or, worse, remain speechless. It, therefore, confronts and poses (to itself) only answerable questions. This way, it remains confined to a fabulous, legendary, contradiction-free domain. It ignores other questions altogether' (Vaknin 2005, p. 27). Remarkably, a wide range of females accept such ideologies and conceive them never 'erring' to the extent that they pass them as real and true.

Cinderella Complex ${ }^{9}$ or the myth of the knight protector is the natural extension to the phallic stage that 'entails a relational complexity in feminine self-definition or personality' (Chodorow 1978, p. 93). Rosa's two knight protectors are her father and Jesus. Abandoned by her father after they move to New York, she realises that she is vulnerable because of her black skin, angelic behaviour, ignorance and submissiveness. Yet, her saviour of this manifold subalternity is Jesus. He makes of her a Cinderella on a throne of power, superiority and knowledge. In a nostalgic tone, Roas narrates:

It was real goody goody. The kids at school used to call me 'Bama' and shit and make fun of me because I wasn't down with the shit they knew from birth or some shit. It was kind of drag at first, but then I met Jesus and he hipped me to a lot of shit about living in New York. Stuff I really needed to know, right? And plus, he was real fine and real cool and a Puerto Rican [My emphasis]. (Chain 1991, p. 278)

For Rosa, Jesus is not a 'nigga,' the title with which she stamps the people of whom she is angry. He is an invaluable asset to this misguided teenager because he helps her cope with the New York society. Despite Jesus forsakes her and repeatedly acts cowardly, Rosa, in her solitary confinement, keeps, for a long time, nurturing the hope that her prince charming will rescue her, 'May be Jesus will rescue me . . Come busting up in here with the Fire 
Department' (Chain 1991, p. 276). But, he never does. He neither hates nor forsakes her; simply, he is too coward to confront the reality or to take a positive action. Thus, the disillusioned Rosa discovers that her real hero and prince charming is her father towards whom she hoards a great affection on a quasi-Electra Complex fashion. It is her father who rescues her from the dope addicts who are ready to murder anybody for a minor reason. Similar to any Cinderella, Rosa desires to 'be part of somebody else' and 'to get into the driver's seat' of 'the man's world' (Dowling 1981, p. 2, 54). Under male authority, however, she will never do; the patriarchal ISA will ever thwart that desired type of authoritative subjecthood.

On the other hand, the majority of the inmates, in Big Butt Girls, Hard-Headed Women, are disillusioned Cinderellas. It seems that Regina Brown has suffered when she has been an innocent Cinderella. Before and after her imprisonment, she asserts that she is the sole controller and protector of herself. She, shamelessly, declares that she is a prostitute; as if announcing that she will not be any more deceived by the male world. She always repeats, 'I am a prostitute, straight up. I decided a long ago, wasn't no man gonna tell me what to do [sic]. I'm a full-grown woman, straight up and down. Or my name ain't Regina Brown' (BBG 1990, p. 368). Regina's complete independence is, probably, the reason behind murdering her. Indeed, a black woman's struggle for sexual autonomy is similar to 'a struggle against fearful and overwhelming odds, which often ended in a horrible death' (Cooper 1991, p. 711). As for Mama Pearl, she hates corrupt males who deceive the inexperienced and naïve females; namely, 'the big butt girls,' as they are called in the play, for the sake of prostituting them or selling them the dope. It is also painful for Mama Pearl to see these females end up pregnant; yet, more painful is to behold the babies of these lost Cinderellas deposited to child protective services or 'flush[ed] . . down the toilet than grunt them into the world' ( $B B G$ 1990, p. 370). On the other hand, there is Lena Sorrentina who is, in every aspect, a real 
Cinderella who is loved and protected by the male world. However, she loses all the day she breaks her leg; her career as a ballerina ends so as her father's love. She is destroyed by her father who is prince charming when expels her out of the house after discovering that she is an addict. Another Cinderella is Doris who clinches to an ex-con, Big Willie, so as to protect her and her baby. Yet, the reverse happens; she is sent to prison because it is she who defends him and her baby against the assault of a policeman. However, she still believes in her boyfriend.

Cinderella Complex is the short cut to masochism. In spite of the inner strength of the females in Chain and Big Butt Girls, Hard-Headed Women, they are subject to processes of conquering and domination; they need to act like a Cinderella, including those women who could develop self-esteem. In fact, this is conceived as a psychological desire for rape in which a woman plays the role of the passive recipient who is conquered and dominated. Molly Haskell confirms that she has discovered that "particularly those women who have self-esteem, who are independent and sexually active have the fantasies in which rape plays a part,' however, 'none of these women would give up' (Haskell 1987, p. 11). These fantasies are the essence of the masochism of women which is "mostly just adaptation to unsatisfying and limiting circumstances' (Thompson 1964, p. 133). Masochism has ever been conceived the bait that makes women think that they are more attractive to men. 'Some of us,' says David Gerrold, 'has learned that we can succeed and survive at a higher level if we express our paranoia in a way that makes us attractive to the people we want to be attractive to' (Gerrold 1988, p. 28-29). Accordingly, females' masochism is typical to such paranoia. Rosa's mother, grandmother, Paula and Jesus' mother willingly yield to this psychological rape; exactly, masochism, so as to keep themselves attractive to their male partners. The result is that they lose their self-esteem and whatever gifts and assets they possess; including the expression of femininity. Playing the role of a silent partner, Rosa's mother loses her 
attractiveness to her daughter, as well as, her male partner who overworks her like a man. Similar to her is Jesus' mother who endures beatings, bad behaviour and an addict prince charming of a boyfriend in an attempt to reform him with her masochistic attractiveness. Against her expectations, however, her masochism precipitates her death. Compared to her is Paula whose attractiveness and beauty are the bait that is conducive to her destruction. She becomes a pregnant semi-prostitute who satisfies the 'male ideology of assault (the mass psychology of the conqueror)' when 'viewing females as anonymous, panting playthings, adult toys, dehumanized objects to be used, abused, broken and discarded' (Brownmiller 1975, p. 394). Her developed sort of attractiveness makes her meet the end of an anonymous disposable object.

Rosa and Regina Brown suffer from a semi-identical sort of prostitution at the hands of male aggressors with killer instinct to the extent that they, consciously, love the pains of abuse. Though Regina is not lesbian, she lets the lesbian inmates couple with her because she believes that: 'Everybody and anybody will use you so you best get to using first' (BBG 1990, p. 388). Rosa also realises that Jesus uses her; he rejects coupling with her but teaches her to publicly masturbate in front of other males so as to procure money. His magical word that makes her blindly obey him is calling her by her Christian name, 'Rosa.' Her name is the only force providing her with self-assertiveness and keeping her high self-image; in a word, it saves her from the danger of being 'anonymous' 'plaything'. Rosa gets used to such practice that Jesus, for his benefit, euphemises when he calls it a game. She also deems of it an appropriate expedience that may help her escape the grip of dope addicts. If her father did not bust in at the right moment, she would have lost her virginity and easily, slipped into prostitution. The masochism of these women is the testimony of society-created neuroses. This is in contradiction to the common false belief based upon real scientific facts that takes of 'menstruation, defloration, rape, birth, the nature of heterosexual encounters and 
lack of muscles seem to indicate that the female was built to submit, to endure physical pain' (Horney 1967, p. 78). On the other hand, Lena Sorrentina, in spite of her strong muscular built and former self-assertiveness, cannot endure the pain of lack of self-esteem. The dope is her way to overcome the agony of low self-image, as it is the only means that helps her dance. Yet, the effectiveness of the dope lasts for short period. Thus, she had to be submissive when she chooses to embrace it until she loses her subjecthood, distinguished social position and, finally, sane mental faculty. Lena Sorrentina's masochism is not the result of woman biology but psychological vulnerability. She is compared to Jesus and the boyfriend of Jesus' mother whose inability to cope with the reality urge them to be servile to the devastating power of the dope. Submitting to the repressive patriarchal hegemonic ISA turns a female into a mere object whenever she attempts to gain distinguished subjecthood through performance and relations to the others and the social institutions. In confirmation, Vaknin argues:

People relate to the condition of existence through the practice of ideology. Contradictions are smoothed over and (real) problems are offered false (though seemingly true) solutions. Thus, ideology has a realistic dimension - and a dimension of representations (myths, concepts, ideas, images). There is (harsh, conflicting) reality- and the way that we represent it both to ourselves and to others. (Vaknin 2005, p. 30)

These females have unconsciously turned themselves into objects in an attempt to be attractive so as to 'relate to the condition of existence' as a gateway to attain subjecthood. Their problem is that they do not pay attention to the unreal or false dimension of ideology which is inherent in the 'dimension of representations.'

Chain and Big Butt Girls, Hard-Headed Women explore a purely African American world where the dominant ISA interpellate females. Depicting other characters belonging to different ethnicities; such as Paula, Lena Sorrentina, Jesus and his mother serves 
strengthening the concept that there is no dialogue between the feminist discourse in the Western World and that in the Third World, whether African American or Hispanic which are two different realms where there is 'a different hierarchy of importance,' that necessitates the feminist discourse to lag behind major socio-political issues. Therefore, 'it is important to isolate the problems which are specific to Africa or perhaps the Third World in general' (Petersen 1984, p. 251). The problems of Rosa's family, Jesus' family so as that of the inmates are these of Third World people, no matter if they live over the land of a First World country. Typical to any Third World society, their vital problems are those of poverty, education, ignorance and isolation. Comparing them to others females belonging of white European origin, namely, Paula and Lena Sorrentina, it is perceived that their feminine discourse is different. Paula's interest is enjoying a revolutionary free sexual life, while Lena Sorrentina's is becoming a ballerina; a delicate career which is sought by middle or the upper-middle classes. In a word, the feminist discourse in the Third World suffers from being 'colonize[d]' by the Eurocentric one in which the Western feminists gear a 'process of hegemonization and systemization of the oppression of women' disregarding the 'fundamental complexities and conflicts which characterize the lives of women of different classes, religions, cultures, races and castes' (Mohanty 1984, p. 260). In this sense, the interpellation of females in Third World countries or realms; including the African American, is very complex. The fundamental problem of Rosa is that she hoards the ambivalence of two contrasted realms that are enfolded within the boundaries of the same country. An African-American woman is not much different from her sisters in Africa or the Third World. Nonetheless, Rosa aspires to break through so as to gain control over her body and sexuality, and the freedom to make her own decisions the same way that any white European woman does. These notions lead her to create a 'Third Text' of her own through which she is interpellated. At first, she tends to Jesus deeming that he belongs to a better civilisation due to 
his knowledge of the New York world and his Puerto Rican origin. Approaching him, she discovers that he is not different; he is another 'nigga'. Developing deeper insights during incarceration is the force that urges Rosa to develop an ISA of her own that would help her gain control over her future life.

Compared to Rosa, Rhodessa Jones attains her aspired freedom and control through creating her ISA that she spreads when she helps other oppressed females; namely, the inmates who are battered and marginalised. 'I'm not interested in art for art's sake,' declares Rhodessa Jones, the acclaimed San Francisco-based performer, teacher, writer, and social activist. For her, art 'has to be about social change. It has to be able to save lives' (Schiffman 2019). High self-image, self-respect, action and assertiveness are Jones' 'Third Text' which enables her to invade the bastion of patriarchal authority and dominance; in other words, the patriarchal SA. Through her plead for unity, 'Can a body, catch a body?' (BBG 1990, p. 366), that is repeated all over the play, she teaches the marginalised women how to control their fate and to be capable of generating a double-voice until they assume a unified one whenever they become in contact with the patriarchal ISA and social culture. Playing not only the role of the aerobic teacher to the inmates, but also that of a psychotherapist, Rhodessa Jones invades the male world and wins their esteem and respect. She narrates in this live-show, which is based upon true stories, that when she returned back home after playing this piece, the San Francisco's Sheriff's Department Work Furlough Program asks her to perform it in front of seventy men, though she asserts that 'this is a feminist theatre piece.' Soon after, she receives her 'first contact to do a run in San Francisco' (BBG 1990, p. 376). Furthermore, her twenty-five years old nephew sends her a letter from his penitentiary in which he expresses his love and respect and also confides to her his feelings and aspirations. In brief, Jones' struggle pays through assiduous efforts and refusing to give up or work within framework pre-determined by patriarchal ISA. The 
principal asset of her success is repudiating gender-roles promoted by the patriarchal ISA no matter if that would mark her Mad. Her example does not only teach other females but also males that they have more control over their lives and fate more than they might acknowledge. Rhodessa Jones succeeds both as a human and teacher because she does not forsake her natural gender-role, love, selflessness and motherhood. From an Althusserian viewpoint, Rhodessa Jones and her likes are accounted heroic teachers. 'Those teachers who,' Althusser confirms, 'in dreadful conditions, attempt to turn few weapons they can find in the history and learning they 'teach' against the ideology, the system and the practices in which they are trapped . . . are a kind of hero' (Althusser, "Lenin before Hegel” 1969, 126). Jones' style is initiating a competing culture industry at the other polarity of the patriarchal ISA. Through her ideologies that stamp her Mad, Jones interpellates females (and, somehow, males) and heroically teaches them to deconstruct the metaphorical representation into which females are incarcerated. Her primary objective is unveiling the false dimension of such representation.

Compared to Jones, Rosa is against the idea of victimhood. In her incarceration, her mechanism of ego defense in Day One and Day Two is denial, then intellectualism, as she learns all about her feelings and begins changing them into ideas. Thus, she gets a better understanding of her situation and how Jesus deceives her under the sham notions of independence, freedom and experience. Developing a considerable mental health, Rosa matures in the sense that she begins consciously performing the unconscious, in accordance with Freud's statement, 'Where id was there ego shall be' (Freud, New Introductory 1933, p. 58); it is Rosa's ego that assists her overcome her ordeal. Rosa eliminates her last mechanism of ego defense when she realises that she, unconsciously, starts being transformed into an Angel who voluntarily loves her incarceration and invisibility. 'At least in here,' says Rosa, 'ain't nobody fucking with me. I got food. I got a bathroom. I even got t.v. and shit, so 
how bad can it be? (Suddenly angry)' (Chain 1991, p. 294). Rosa becomes 'suddenly angry' because she realises that she slips into the pit of society-generated female masochism that will render her an 'Angel in the House.' She quickly telephones Jesus, though she is not any longer in love with him. Authoritatively, she violently chides him showing extreme selfcontrol either in her social relations or inwardly. She confirms, 'I can handle myself, I been telling you that. . . . I ain't scared of no crackhead niggas. . . . not even you!' (Chain 1991, p. 295). She also assures that she got rid of the dope addiction and never wants to return to it once more, 'And I handled it! I am handling it! (Chain 1991, p. 295). Consciously, Rosa also confronts him with his reality as a 'coward addict'. Obviously, Rosa phones Jesus to get in touch with her ego wounds and traumas in her relationship with the outer world. She acknowledges herself not as a victim anymore, but as a human being who has a free will and responsibility towards her own choices and life; these are the primary steps to autonomous subjecthood. Furthering her self-development, she consciously leaves with Jesus so as to test her newly acquired strength. Probably, the moment she would know that she totally overcame her traumatic yearning for Jesus as a symbol of powerful street-representative; it would be the same moment when she would leave him. It is also possible that if she reaches an optimal psychological functioning ${ }^{10}$, she will turn into another Rhodessa Jones whose struggle pays. Yet, if she would not cultivate self-balance, she might turn into another Doris who is caught neither for addiction nor for prostitution, but for protecting her family. In her literal incarceration, Rosa, the teenager female, develops a clear understanding of what Althusser (Althusser, 'Ideology' 1969, p. 146) calls 'the unconscious character of ideology' that Vaknin dubs as 'the Third Text' that is inherent in the social practices and the patriarchal ISA. Similar to Jones, she discovers her subjecthood through clinching to her personal ideology which, finally, offers her not a negative interpellation but a 'competing interpellation.' 
Expectedly, Rosa's example will also make of her a heroic teacher whose example will be followed by others.

The prejudiced attitude towards females is debunked by analysing the metaphorised representation of females within the context of the Angel/Mad binary from the perspective of Althusser's concept of interpellation. Obviously, such binary is originated in the patriarchal ISA that serves the repressive SA. Passing as true the patriarchal ISA, females hoard it as ultimate truth and become so blinded to observe its false legendary dimension. Unexpectedly, violence and repression enacted against females, so as to perpetuate the hegemony of the dominant power structure, creates an opposing polarity which targets dismantling the false and legendary aspects of female role and position which are created by the hegemonic patriarchal ISA. Cleage's Chain and Jones' Big Butt Girls, Hard-Headed Women appropriate the notions of interpellation through staging true stories that make the reference plays appear as 'a pre-existing structure . . [that] interpellates the spectator, so constituting him/her as a subject' (Lapslay and Westwake 1988, p. 12). This process of interpellation entails representing a feminist discourse that accentuates the notion of defying society-created neuroses and patriarchal gender-roles, which are accounted as madness by the patriarchal ISA. Nonetheless, they are the gateway for any female to overcome the risk of ghettoising her capabilities, notions and interests. 


\section{$\underline{\text { Notes }}$}

${ }^{1}$ Pearl Cleage (1948- ) is an African-American playwright, novelist, essayist and poet. After high school, Cleage attended Howard University where she majored in playwrighting.

${ }^{2}$ Rhodessa Jones (1948- ) is a performer, writer, lecturer and teacher, as well as, a co-artistic director of Cultural Odyssey; a San Francisco-based non-profit performing arts organisation and founder of the Medea Project: Theater for Incarcerated Women. It is a program designed to promote incarcerated women's self awareness and self-esteem through the creation and production of theatre pieces based upon personal histories.

${ }^{3}$ Ideological State Apparatus (ISA) and State Apparatus (SA) reveal how Louis Althusser complicates Karl Marx's understanding of the relation between base and superstructure. Althusser does not reject Marx's model, but proposes to distinguish between ISA and SA. For Althusser, SA is repressive and includes the administrative agencies in the state, such as: 'the Government, the Administration, the Army, the Police, the Courts, the Prisons, etc.' (Althusser, "Preface to Capital Volume One" 1969, p. 96). These agencies function 'by violence' as they impose punishment or privation, at some point, in order to enforce power. As for the ISA, there are: the religious ISA (including the system of the different public and private schools); the family ISA; the political ISA; the trade union ISA; the communications ISA (press, radio and TV, etc.); the cultural ISA (literature, the arts, sports, etc.); . . etc. For more information see Althusser, Louis (1971). Lenin and Philosophy and Other Essays. (trans.) Ben Brewster. New York: Monthly Review Press.

${ }^{4}$ From now on, I shall refer to Ideological State Apparatus as ISA and to State Apparatus as SA. 
${ }^{5}$ For the best discussions of the Victorian feminine ideal, see Houghton, Walter E. (1957). The Victorian Frame of Mind. New Haven. pp. 341-43; and Alexander Welsh's theory of the Angel in the House in The City of Dickens, London, 1971, pp. 164-95.

${ }^{6}$ Ecofeminism is the relationship between woman and nature. It 'begins with the assumption that from a historical perspective, woman has been associated with nature, and seeks to analyze the development of this association and how it has led to the domination and the exploitation of woman and nature as resources in patriarchal society' (Devine 1992, p. 29).

${ }^{7}$ Freud's theory of the psychosexual stages of development proposes that the sexual instincts forming the personality pass through five stages: the oral, the anal, the phallic or the Oedipal, the latency, and the genital.

${ }^{8}$ For further reading see:

Freud, Sigmund (1933). "Female Sexuality." Civilization and its Discontents. (ed.) James Strachey. 24 Vols: 22. London: Hogarth Press, 1953-1974. 223-43.

--- (1933). New Introductory Lectures on Psychoanalysis. New York: W. W. Norton.

--- (1933). "Femininity." Psychoanalysis and Feminism. (ed.) Juliet Mitchell. New York: Pantheon, 1974. 60-98.

9 See Dowling, Colette (1981). The Cinderella Complex: Women's Hidden Fear of Independence. New York: Simon \& Schuster Pocket Books.

${ }^{10}$ According to Freud, 'optimal psychological functioning' is the status when an individual does not experience too much anxiety, too much pain, does not get into too much trouble in her/his social environment, and when the personal resources are used as adaptively as possible. In a word, it is the status of adaptation to the environment and the balance between the environment and one's inner forces. 


\section{Works Cited}

Althusser, Louis (1969). "Ideology and Ideological State Apparatus." Lenin and Philosophy and Other Essays. (trans.) Ben Brewster. New York: Monthly Review Press, 1971. $127-188$.

--- (1969). "Lenin before Hegel." Lenin and Philosophy and Other Essays. (trans.) Ben Brewster. New York: Monthly Review Press, 1971. 107-126.

--- (1969). "Preface to Capital Volume One." Lenin and Philosophy and Other Essays. (trans.) Ben Brewster. New York: Monthly Review Press, 1971. 71-101.

Anonym (2020). "Rhodessa Jones: African and African American storytelling." Alliance for California Traditional Arts (Jan.). actaonline.org 6 March 2020 <https://actaonline.org/profile/rhodessa-jones/>

Baym, Nina (1984). "The Mad Woman and her Languages: why i don't do feminist theory." Feminisms: An Anthology of Literary Theory and Citicism. (eds.) Robyn R. Warhol and Diane Price Herndl. New Jersey: Rutgers University Press, 1991. 154-67.

Brownmiller, Susan (1975). Against Our Will: Men, Women and Rape. New York: Simon \& Schuster.

Carby, Hazel V. (1995). Reconstructing Womanhood: The Emergence of the Afro-American Woman Novelist. Chicago: University of Chicago Press.

Chodorow, Nancy (1978). The Reproduction of Mothering: Psychoanalysis and the Sociology of Gender. Berkeley: University of California Press.

--- (1976). "Gender, Relation and Difference in Psychoanalytic Perspective." The Future of Difference. (eds.) Hester Einstein and Alice Jardine. Boston: G. K. Hall, 1986. 4-19.

Cixous, Hélène (1976)."The Laugh of the Medusa." Signs vol 1, 4. p. 875-93.

Cooper, Anna Julia (1991). "The Intellectual Progress of the Colored Women of the United States since the Emancipation Proclamation." World's Congress, 699-781. 
Dal Maso, Juan and Warren Montag (2018). "Reassessing the Legacy of Louis Althusser on His 100-Year Anniversary: An Interview with Warren Montag." Left Voice (Oct. $16^{\text {th }}$. leftvoice.org 5 Feb. $2020<$ https://www.leftvoice.org/Reassessing-the-Legacyof-Louis-Althusser-on-His-100-Year-Anniversary-An-Interview-with-Warren> .

Devine, Maureen (1992). Women and Nature: Literary Reconceptualizations. Metuchen, N. J.: The Scarecrow Press, Inc.

Dowling, Colette (1981). The Cinderella Complex: Women's Hidden Fear of Independence. New York: Simon \& Schuster Pocket Books.

Ealm, Jr., Harry J. (1996). "Colored Contradictions in the Postmodern Moment: An Introduction." Colored Contradictions: An Anthology of Contemporary AfricanAmerican Plays. (eds.) Harry J. Elam, Jr. and Robert Alexander. New York: Plume Book. 1-19.

Freud, Sigmund (1933). New Introductory Lectures on Psychoanalysis. New York: W. W. Norton.

--- (1933). "Femininity." Psychoanalysis and Feminism. (ed.) Juliet Mitchell. New York: Pantheon, 1974. 60-98.

Fuchs, Christian (2019). 'Revisiting the Althusser/E. P. Thompson-Controversy: Towards a Marxist theory of communication.' Communication and the Public (Mar. $18^{\text {th }}$ ). https://doi.org/10.1177/2057047319829586. <https://journals.sagepub.com/doi/abs/10.1177/2057047319829586>.

Gerrold, David (1988). When H.A.R.L.L.E was One. New York: Bantam.

Gilbert, Sandra M. and Susan Gubar (1988). No Man's Land: The Place of the Woman Writer in the Twentieth Century. 3 Vols: I, The War of Words. New Haven: Yale University Press. 
Haskell, Molly (1987). From Reverence to Rape: The Treatment of Women in the Movies. Chicago: Chicago University Press.

Horkheimer, Max and Theodor Adorno (1979). The Culture Industry: Dialectic of Enlightenment. London: Verso.

Horney, Karen (1967). Feminine Psychology. New York: W. W. Norton.

Janiak, Lily (2018). 'Rhodessa Jones is 'telling the truth and practicing revolution' at Brava." San Francisco Chronicle (Aug. 21 ${ }^{\text {st }}$ ). sfchronicle.com 6 March 2020 <https://www.sfchronicle.com/performance/article/Rhodessa-Jones-is-telling-thetruth-and-13172135.php>.

Lapslay, R. and M. Westlake (1988). Film Theory: An Introduction. Manchester: Manchester University Press.

Martin, Michel (2014). “Pearl Cleage Opens Up.” NPR (May 1 1'). npr.org 1 May 2014 <https://www.npr.org/2014/05/01/308619983/playwright-pearl-cleage-opens-up> .

Mims, Morgan (2016). "Pearl Cleage: Making Life in the Theatre." Howlround: Theatre Commons (Jun. $4^{\text {th }}$ ). howlround.com 6 March 2020. <https://howlround.com/pearlcleage>.

Mohanty, Chandra Tolpade (1984). "Under Western Eyes: Feminist Scholarship and Colonial Discourses." Post-Colonial Studies Reader. (eds.) Bill Ashcroft, Gareth Griffiths and Helen Tiffin. London: Rutledge, 1999. 259-63.

Moi, Toril (1985). Sexual/Textual Politics. London: Methuen.

Petersen, Kirsten Holst (1984). "First Things First: Problems of a Feminist Approach to African Literature." Post-Colonial Studies Reader. (eds.) Bill Ashcroft, Gareth Griffiths and Helen Tiffin. London: Rutledge, 1999. 251-54.

Robins, Roth (2000). Literary Feminisms. New York: St. Marlin's Press. 
Rosaldo, Mitchell Z. (1980). "The Use and Abuse of Anthropology: Reflections on Feminism and Cross-Cultural Understanding." Signs 5.3, 389-417.

Sawyer, Keith (2002). "A Discourse on Discourse: An Archaeological History of an Intellectual Concept.” Cultural Studies 16 (3), 433-56.

Schiffman, Jean (2019). 'Activist Performer: Rhodessa Jones.' American Theatre: A Publication of Theatre Communications Group (Nov. 19). americantheatre.org March 5, 2020. <https://www.americantheatre.org/2019/11/19/activist-performer-rhodessajones/>.

Showalter, Elaine (1981). "The Female Tradition." Feminisms: An Anthology of Literary Theory and Criticism. (eds.) Robyn R. Warhol and Diane Price Herndl. New Jersey: Rutgers University Press, 1991. 269-88.

Thompson, Clara (1964). On Women. New York: New American Literary.

Vaknin, Sam (2005). Malignant Self-Love: Relationships with Abusive Narcissists. Scopje, Republic of Macedonia: Lidija Range Lovska.

Bio-note

Naeema Abdelgawad is an ex-Fulbrighter, assistant professor, and professional translator/ interpreter. She is a published fiction and non-fiction writer: poet, short story writer, novelist, journalist and cinema/literary critic in both English and in Arabic languages equally. She is also a published scholar in the premise of cross-cultural, ethnic, gender and interdisciplinary studies as well as translation theory. 